УДК 821.163.41.09 Христић Јован https://doi.org/10.18485/godisnjak.2019.14.14

Тијана М. Копривица*

Универзитет у Београду

Филолошки факултет, докторанд
Оригинални научни рад

Примљен: 15. 09. 2019.

Прихваћен: 11. 10. 2019.

\title{
„ОД ТЕБЕ ДО ЗЕМЉЕ, ОД ТЕБЕ ДО ЗВЕЗДА, ИСТО ЈЕ” - ЈЕДАН ПОГЛЕД НА ПОЕЗИЈУ ЈОВАНА ХРИСТИЋА
}

Намера овог рада биће да понуди један поглед на поезију Јована Христића из перспективе Нове критике, коју је Христић и са̂м као посредник између англо-саксонског критичарског круга и српске књижевности усвајао и уважавао, како у писању поезије, тако и у критичком мишљењу о њој. У овом случају, пажња ће превасходно бити усмерена ка оним питањима којима се Христић бавио тумачећи поезију других песника, односно односу поезије и филозофије који га је окупирао, те ће се тако ово питање истраживати кроз четири упоришне тачке: традищија, путовање, простор и однос нужности и случајности.

Кључне речи: Јован Христић (1933-2002), Нова критика, поезија, филозофија, српска књижевност, традиција, путовање, простор, нужност, случајност.

\section{Поезија и филозофија}

Јован Христић се са Новом критиком упознаје у њеном изворном облику - преводећи Елиотове есеје и поезију, приређујући књигу Елиотових есеја - због чега се може рећи да је међу најзаслужнијима за имплеменитрање новокритичарске књижевно-теоријске мисли у српску књижевност, 
посебно када се узме у обзир да је баш он приредио први зборник који групише оне текстове који су кључни за Нову критику. Прве примене овог приступа, као и прва размишљања о ставовима које новокритичари износе, Христић објављује у своје две књиге, Поезија и критика поезије, из 1957. године, и Поезија и филозофија, из 1964. године. У овим књигама се налазе текстови у којима можда највише долази до изражаја Христићева мисао о поезији, како сматра Марко Аврамовић (Аврамовић 2013: 260). Иако 1957. године, када се појављује Христићева књига Поезија и критика поезије, Елиотови есеји тек почињу да бивају превођени на српски језик, већ и летимичним погледом на ту Христићеву књигу, која је збир есеја насталих у периоду између 1951. и 1957. године, постаје јасно колики су утицај Елиот и његови следбеници извршили на Христића и на општи приступ разумевању модерне поезије и поезије уопште. Поред есеја који су посвећени Рилкеу, Бодлеру и Спендеру, у овом издању ће се наћи и неколико текстова који са проблемског становишта преиспитују модерну поезију и критику поезије. У „Поезији и критици поезије”, „О модерном у поезији”, „Белешци о методу енглеске поезије” и „Форми, поезији и емоцији" Христић ће више пута указивати на Елиотова, Паундова, Ричардсова и достигнућа других песника и књижевних критичара, те ће од њих полазити у својим размишљањима и тумачењима.

Макар се задржали само на наслову Христићевог есејистичког списа из 1964. године (само годину дана после првог појављивања Елиотових есеја у нешто обимнијем облику код нас и три године након публиковања Елиотовог најпознатијег песничког дела у Христићевом преводу $\left.{ }^{1}\right)-$ Поезија и филозофија, и више се него јасно уочава утицај који је истоимени Елиотов текст имао на нашег књижевног критичара. Доводећи своју књигу сугестивним насловом у директну везу са англо-саксонским мислиоцем, Христић настоји да поведе дијалог и да понуђеном и нашем контексту прилагођеном мисаоном апаратуром протумачи српску књижевност.

Посебан однос поезије и филозофије који Христића интересује заснива се на ставу да савремена поезија „поново стоји равноправно са филозофијом у такмичењу, ако се тако може рећи, у одговарању на суштинска питања човекове егзистенције" (Христић 1964: 21-22), па је овај однос и приказан на примеру опуса тројице српских песника - Јована Стерије

${ }^{1}$ Елиот 1961: Т. С. Елиот, Пуста земља, у: Летопис Матице српске, 137, 387, 4 (април 1961), Нови Сад: Матица српска, 322-335.

Елиот 1963: Т. С. Елиот, Изабрани текстови, Београд: Просвета.

Пре превода Изабраних текстова, од есејистичких дела, преведен је само текст „Поезија и филозофија” 1957. године и објављен у Пољима и „Шта је класик?” 1960. године, који је објављен у Путевима. 
Поповића, Лазе Костића и Душана Матића. Сходно томе, сматрамо да би било адекватно да и наше истраживање Христићеве поезије усмеримо ка односу поезије и филозофије, који је за њега био толико важан, при чему пажња неће бити усмерена на стварање каталога или селекције филозофских проблема, теорија или имена (Радојчић 2016: 213), која се на онај или овај начин појављују како у есејистици, тако и у поезији. Будући да се у Христићевим поменутим књижевним истраживањима као најважнија питања намећу она која се тичу човека - „шта је он, каква је његова судбина, какви су његови изгледи у свету онаквом какав јесте" (Христић 1964: 20), и наше тумачење Христићеве поезије ће водити ка одговорима на та питања, као и ка томе да се прикаже на који начин су ти одговори обликовани у поетски исказ.

\section{Традиција}

Прва песничка збирка Јована Христића објављена је 1954. године и насловљена је Дневник о Улису, при чему се чини да већ тада Христић успоставља сопствени корпус традиције из које црпи песничку имагинацију и инспирацију (Лалић 1996: 15). Већ у самом наслову садржан је јак симболички потенцијал, а са њим и бар две асоцијативне линије могућих тумачења. Прва линија асоцијације креће се трагом књижевног наслеђа које име Улис са собом носи. Истовремено се евоцирају античка грчка и античка латинска традиција, будући да се уз латински облик имена митског јунака (прво у поменутој збирци, а потом у песми под насловом Улис) јавља и грчки облик имена - Одисеј. О овом необичном поступку подробно полемише Александар Петров у својој студији „Христићев Улис", трагајући за свим песничким узорима и изворима који су могли постојати на Христићевом песничком хоризонту, те успостављајући ток наслеђа у елиотовском духу који полази од Хомерове Одисеје, преко Вергилијеве Енеиде, Дантеове Божанствене комедије, односно Пакла, све до нешто модернијих транспозиција овог мита, као код Тенисона, Џојса, Бродског и других. Петров закључује да је сједињавањем два традицијска тока Христић желео да искаже своје опредељење, односно „да укаже на двоструку укорењеност своје поезије: у грчку традицију, као традицију потоњих европских књижевности, али и у каснију песничку традицију Западне Европе" (Петров 2009: 82). Друга асоцијативна линија донекле се наставља на прву, будући да у себе укључује још једног писца, старијег од Христића, који инспирацију проналази у митској причи о Одисеју, те тако Христић посредством жанровског одређења из наслова песничке збирке, 
„дневник”, као и употребом предлога „о” уз њега, још више продубљује дијалог са поетиком Милоша Црњанског и његовим раним делима - Дневником о Чарнојевићу, али и Лириком Итаке.

Христићево обрачунавање са овим својим делом одавно је познато књижевној јавности и потврђено тиме што ова збирка никада више у целини није прештампавана, већ се само пет песама појављивало у наредним издањима Христићевог песничког опуса. Ипак, специфично осећање за историју, за оно што је у њој ванвременско, доследно ће се јављати и у познијем стваралаштву, и то као оно што ће сам Христић назвати „другом традицијом". О овом појму Христић је први пут експлицитно говорио поводом Изабраних и нових песама (1969) Ивана В. Лалића, при описивању токова савремене српске поезије и исхода полемика између модерниста и реалиста педесетих година XX века, када је и објаснио да она подразумева „трагање за једном 'другом традицијом' у нашој књижевности, која ће се битно разликовати од оне канонизоване, што се до тада није стављала у питање, бар не озбиљније и систематскије" (Христић 1969: VII-VIII).

Песма Улис ${ }^{2}$, осим особеног измењеног прежитка младалачке поезије, представља и парадигматичан пример третирања митологије у Христићевом стваралаштву. Одисеј се, као најдоминантнија фигура, јавља у различитим облицима, понекад сасвим очигледно, понекад тек у алузији на митолошки/историјски/епски контекст којем припада, а уз њега се појављују и Пенелопа и Данајци, по којима и Христићеве песме добијају своје наслове. У Улису седам пута анафорички употребљено име Одисеј уз себе везује многе видове постојања и самим тим отвара простор могућности поистовећивања са јунаком представљеним сплетом контрадикторних особина. Стога, „оног правог”, „оног великог путника” (Христић 1996: 27) 3 можемо видети усамљеног у полупразној хотелској соби која подсећа на болницу, како лута улицама града, као образац парадоксалности - као неког ко има све, а истовремено нема никог. Читава песма је у настојању да се изнова изгради идентитет митског јунака, што се чини понављањем показне заменице „онај”, да би се каталог особи-

${ }^{2}$ У Сабраним песмама Јована Христића које је приредио Иван В. Лалић ова песма се налази на првом месту у првом „циклусу”, будући да испред ње Лалић као пролошку песму поставља Вечерњу песму. У Сабраним песмама које је приредио Саша Радојчић, као и у књизи из едиције Десет векова српске књижевности посвећеној Јовану Христићу, коју је приредила Бојана Стојановић Пантовић, песма Улис се налази на првом месту, при чему Радојчић даје напомену о враћању песама Вечерња песма и Федру на места која им хронолошки припадају, што Б. Стојановић Пантовић очевидно следи при састављању антологијског издања.

${ }^{3}$ Како ће сви стихови бити пренети према оном облику у ком се налазе у издању Христић 1996: Ј. Христић, Сабране песме, Нови Сад: Матица српска, тако ће њихово навођење у раду бити означено бројем у загради. 
на последњи пут једноставно потврдио и потцртао личном заменицом „он” у финалном стиху. Градећи идентитет митског јунака у не-митским околностима, Христић заправо успева да изгради идентитет савременог човека, чије је путовање - путовање у дословном значењу, али и путовање метафорички узето као живот - условљено не мотивацијом својственом херојском свету и божанском интервенцијом, већ културним обрасцима којим појединац као део друштва подлеже.

\section{Путовање}

Модерна реинтерпретација мита о Одисеју подразумева и рекреирање контекста у коме актер борави, али чак и при томе Христић задржава два битна елемента - путовање и морски амбијент, који ће у његовој поезији заузимати веома важно место. Неке од песама које садрже ова два, слободно можемо рећи - топоса Христићеве поезије јесу Поново посећена Итака, Бродски дневник и Једно сентиментално путовање по мојој соби.

Прва од поменутих песама насловом јасно алудира на хомерски наратив о Одисеју. Путовање које је наговештено, међутим, није смештено нити у давна времена, нити је Одисеј тај који још једном посећује своју домовину, већ се као основна идеја испоставља медитативно путовање лирског субјекта. Овај процес се остварује понирањем у далеке светове који се налазе између корица књига, дакле интелектуалном активношћу - читањем. Интроспекција коју лирско ја над собом врши отпочиње управо са завршетком чина читања, након чега следи размишљање о сопственој позицији „у ова четири зида” (44), а окончава се, или пак наставља у недоглед, у сновима. У извесном смислу, на основу става и осећања које лирски субјекат изражава у овој песми, може се говорити о поистовећивању лирског ја са протагонистом митског наратива; лирско ја јесте актер путовања и мири се са неизвесношћу његовог исхода. Метафорички схваћено, као и у песми Улис, путовање означава живот, док престанак кретања означава смрт.

Бродски дневник палубног официра Мартина на броду „Санта Мариа” у подтексту крије алузију на причу о Одисеју, а мотивима као што су песма сирена или ружопрста зора, па и самом пловидбом као мотивом, ова веза се појачава и јасније истиче. Мото преузет из Декартове Расправе односи се на објашњење разлога путовања, док се поигравањем са именом брода датим у поднаслову упућује на Колумбову прву експедицију изведену 1492. године. Оба ова поступка одговарају опису путовања морем које је 
дато у овој шестоделној песми, па се тако из три различите перспективе - историјске, филозофске и књижевне - нуди осмишљавање путовања. Паралелним указивањем на догађаје и доживљаје, атмосферу и осећања, Христић своју песму саображава жанровској одредници дневника, коју јој је приписао, док колективним гласом, којим је песма испевана, ову илузију истовремено разара. Чин путовања постепено прелази у други план, па морски амбијент постаје сценографија посезања за разлозима предузимања тог подухвата. У тексту песме ипак изостаје објашњење порива за сталним кретањем, због чега тачан разлог путовању остаје непознат. Песма мора, осека, ветар и таласи као могући разлози стоје изван домена свесне одлуке, те се на крају песме уобличава спознаја о путовању као нужности коју покреће случајност.

Једно сентиментално путовање по мојој соби такође представља интроспективно путовање које почиње и завршава се у истој тачки и које има за циљ помирење са сопственим ја, па се у тој песми може рећи да је смисао путовања најближе наговештен поетским језиком.

\section{Простор}

У вези са путовањем као темом тесно је повезана и идеја простора кроз који се путује. Код Христића је простор представљен на два начина, који се неретко узајамно прожимају и допуњују. Први начин подразумева представљање човека у односу на неограничено пространство, у овом случају симболички изражено морем. У физичком смислу, како је већ и наглашено, човек из Христићеве поезије неретко је доведен у везу са морем, те је тако често присутно путовање морем и рефлексије које одатле проистичу. Због тога, важно је рећи да је Христићево море географски веома прецизно одређено и да је то простор Средоземља, о чему на много места говори у својим есејима ${ }^{4}$, а што се у поезији такође потврђује. Христићево Средоземље није само оно Средоземље Јадранског мора које је блиско нашем културном поднебљу и чије рефлексе проналазимо у српској књижевности без обзира на актуелну политичку ситуацију. Христићево је и оно „друго” Средоземље, супротна обала, а на њој као најважнија тачка

\footnotetext{
${ }^{4}$ Видети есеје „Човек средоземља” и „Чему путовати?” у: Христић, Јован, Изабрана дела (прир. Бојана Стојановић Пантовић), Антологијска едиција Десет векова српске књижевности, књ. 89, Матица српска, Нови Сад, 2016. Такође, обратити пажњу на оно што Христић говори поводом поезије Душана Матића у огледу из Поезије и филозофије: „Била је реч о томе да путовање није само једна пролазна авантура, мењање места, већ стање у коме човек учествује читавом својом егзистенцијом; модус постојања, како би рекао Спиноза, агрегатно стање постојања, и, најзад, један нарочити поглед на свет." (Христић 1964: 107).
} 
Александрија, чиме се остварује и посебна врста традицијске везе према делу Константина Кавафија изражене интертекстуалношћу. ${ }^{5}$ Са друге стране, поред физичког пространства које означава, топоним Медитерана често је покретач и одредиште духовних путовања која се одвијају у најинтимнијим тренуцима које лирски глас проживљава.

Насупрот отвореном простору, у дословном и у пренесеном смислу, који море симболизује, поставља се затворен, скучени простор сопствене собе у коме човек Христићеве лирике проводи своје време. Некад ће тај простор бити експлицитно именован (на пример, у наслову песме Једно сентиментално путовање по мојој соби или у стиховима: „Одисеј онај сам у хотелској соби” (27), „У ова четири зида” (44), „Најзад, у овој соби, затворићемо зидове” (55), „Овде опет, у сопственој соби, као фантом” (35), итд), док ће у другим ситуацијама бити представљен као подразумевана сценографија (у песмама: Увод у генезу, Разговор, Седео је сам, док се ноћ скупьала иза окана, итд). У овим случајевима, соба за Христића и његовог човека из поезије постаје простор напетости, а у таквој атмосфери суочавање са сопством постаје неизоставно, чак и пожељно како би се достигло стање духа које одражава наслов једне од песама: EUTHYMIA - стање у коме душа живи у миру и тишини, неузнемирена страшћу, страхом или сујеверјем.

Посебна врста човековог позиционирања и значење које из њега проистиче остварује се супротстављањем непрегледног морског пространства скучености коју унутрашњост собе значи у једној песничкој слици. Овај поступак се најбоље може издвојити ако се посматрају упоредо циклус песама Mezzogiorno и стихови Бродског дневника. Mezzogiorno настаје као похвала мору и лету, сензуално доживљеним свим чулима и читавим телом, и у дванаест фрагмената носи представу мора у виду апсолутне пуноће: „Немогуће је наћи метафору за море. / Своја сопствена метафора, оно је елемент / који је и прва и последња метафора света; / своја сопствена историја: времена која се слажу једно преко другог, / постајући наслаге светлости, јачи сјај." (96-97). Пратећи стихове који очигледно указују на физичко присуство човека на обали, а који су створени употребом мотива лета, сунца, воде, те песничким сликама које описују сензуални доживљај околине на телу, постепено се гради Христићева сопствена симболика

${ }^{5} \mathrm{O}$ топосу Медитерана у српској књижевности видети више у: Новаковић 2013: Ј. Новаковић, Медитеранска надахнућа у српској поезији XX века: компаратистичка перспектива, у: C. Шеатовић Димитријевић et al. (ур), Acqua alta : међународни зборник радова = miscellanea internazionale. Медитерански пејзажи у модерној српској и италијанској књижевности = Paesaggi mediterranei nelle litterature italiana e serba del novecento, Београд: Институт за књижевност и уметност, 435-453. 
мора, која у извесној мери кореспондира са сродним песничким виђењем мора Душана Матића. Море, као велика метафора света, истовремено је и пуноћа егзистенције и ништавило нужности које својим плаветнилом обухвата читав свет Христићевог човека и опкољава га, и са́мо постајући једна затворена целина: „Тонемо ли у море, или се светлост склапа изнад нас?" (86)

Други вид опонирања и сједињавања две просторне метафоре јавља се у Бродском дневнику, у коме пратећи наратив пловидбе морем, лирски глас преиспитује своја егзистенцијална упоришта. Час спознаје наступа признањем: „Море је око нас, соба је у нама, и отићи из једне / Значи носити једну другу са нама - / Море је око нас али није у нама, / Море је око нас, али соба је у нама." (51) Опредмећивање сопственог духа и његово омеђавање сопственом вољом и успостављеним контрадикторностима којима у овим стиховима сведочимо, доста личи ономе што ће у песми STOICHEIA Христић изразити на нешто једноставнији начин: „Затворен у своје ја као у тамницу” (38). Овакво „опросторавање” човека, на начин да истовремено његове духовне димензије имају супротне вредности, говоре у прилог Христићевом комплексном погледу на бивствовање и подношење истог, као и о амбиваленетности човекове природе у његовој поезији.

\section{Нужност и случајност}

Читањем Христићевих критичких текстова о другим песницима указује се и извесна тенденција бављења питањем односа нужности и случајности и човековог положаја између ове две одреднице. Исто тако, пажљивим читањем Христићеве поезије долази се до закључка да овај проблем Христића занима и у сопственом песништву, те ће се његове манифестације огледати на различите начине. Поменути разлог путовања о коме се поетски расправља у Бродском дневнику налази се у нужности, док се море у Mezzogiorno-у узима као велики разлог свега. У непрестаном кретању и услед тога у сталној промени, намеће се питање где се налази човекова упоришна тачка. Христић питање судбине и учешћа у њој одгонета различитим средствима. Најбројнији су примери у којима се служи митолошким представама, па ће тако неколицина песама говорити о читању судбине из положаја звезда или животном путу одређеном вољом богова. Такве су, на пример, песме Ноћу, изађи да гледаш звезде, гледаш судбине, Свеће, Један од њих устаде и запита и друге. Митска ситуација прорицања судбине из положаја звезда код Христића не даје готов одговор на питање „Шта ће бити?”, већ уместо тога додаје питање о суочавању са 
сопственом судбином. Судбина је представљена као изазов, бачена рукавица која позива на борбу. Остаје недоречено са чиме се човек у међупростору између земље и звезда, како је код Христића позициониран, бори: да ли са препрекама, да ли са животом, да ли са собом, те се произвољност значења поруке прочитане међу звездама додатно наглашава.

Слично ће бити и у песми Те ноћи су се скупили на највишој кули, у којој познавање геометрије омогућава разумевање судбине утиснуте међу звездама, где ће неодређеност Христић приказати на следећи начин: „Јер звезде увек дају одговор смртнима, / Али на које питање, то само оне знају." (76) Оваква поставка ипак пружа, штавише, она намеће нужност човеку да своју судбину самостално одреди без посредних инстанци, те указује на то да човекова одговорност према себи лежи у постављању самог питања. Питање шта је судбина експлицитно се поставља у песми Један од юих устаде и запита. У овој песми судбина, односно човечији живот означена је као воља богова, као уметничко дело богова - кип који се неспретним покретима човека круни (74). Порозност статуе метафорички замењује протицање човековог живота и настоји да га образложи начинима који искључују прихватање последица сопствених потеза.

Богови који одређују судбину помињу се и у песми Свеће. Упаљене свеће представљају гаранцију будућности, светлост ка којој се иде и која се симултано гаси када се достигне. Кључно питање је питање постојања - да ли је то несебични дар богова или замка. Моћ богова је јасно опевана у песми Богови, где су богови приказани као стални, али неприметни део човековог живота. Богови су ти који имају моћ, они воде евиденцију и својом притворношћу проничу у тајне, они се свете (120). Пре него алузија на античке богове одевене у савремено рухо, што свакако може бити, својим ироничним насловом, а затим и ироничним тоном којим се песничке слике ређају, читава песма као да у много већој мери алудира на савременост којој Христић и као песник и као човек припада, а чије је главно обележје неспокој. ${ }^{6}$

У песми Угао проблем односа нужности и случајности дат је на нешто другачији начин. Параболом о два пролазника који се свакако морају срести поставља се питање о поласку у сусрет сопственој судбини. Уколико је све унапред дато, како Христић у овој песми претпоставља, постаје неважно да ли се до тога стиже раније или касније, односно, преостаје само привид утицања на нужно.

${ }^{6}$ Посебно интересантно би било испитати ову тезу узевши у обзир и песму Варвари, у којој се насловом и садржајем експлицитно успоставља веза са Кавафијевом песмом Чекајући барбаре. 
Христићеве пловидбе српском књижевношћу: закључна разматрања

Место које је Јован Христић стекао у српској књижевности својим књижевно-уметничким, есејистичким и културним бављењем тешко да би неко могао да му одузме, иако се повремено стиче утисак да нема превише простора за говор о његовим достигнућима или да се бар тај простор недовољно користи. Овај рад, осим првобитне намере која је на почетку исказана, има за циљ и покушај да се, ослушкујући речи овог песника - јер он то увек јесте, било да пише стихове, драму или есеје - проговори о његовој важности у поретку са онима који су му претходили, као и онима који су певали након њега.

Указујући на домете које је Нова критика остварила у науци о књижевности, о њеним тековинама и утицајима које је извршила на такозване мање књижевности, каква је и српска књижевност у том поређењу, а онда и бирајући управо новокритичарску оптику за тумачење Христићеве поезије, закључци који одатле проистичу сугеришу својствени поглед на свет овог песника и човеково место у њему. Приступајући човековој позицији коју му Христић у својој поезији даје са четири тачке - традищија, $n y$ товање, простор и нужност и случајност, помаља се аутентичан склоп комплементарних околности које човека одређују.

Христићев човек је усамљена индивидуа која напушта потрагу за егзистенцијалним утемељењем, баш онда када највише изгледа као да је тражи, пред интуитивном спознајом да управо у томе и лежи његово метафизичко сидро. Због тога човек представљен лирским гласом у Христићевој поезији никада неће бити у стању мировања. Које год да је врсте лирско путовање које се одвија, физичко или метафизичко, човек и његов дух неће мировати. Непрестана промена која је наглашена и осећањем за протицање времена и идентитет који се мења из тренутка у тренутак сведоче у прилог несталности.

Непостојање дефинитивног облика, метафизичко колебање између пуног и празног, страх од празнине „која тек треба да се дешифрује” (Христић 1964: 107) - horror vacui у теми путовања добија свој коначни облик. Управо ту је Христић и узима реч у дијалогу са нашом књижевном традицијом, и то оном њеном струјом која је изнедрила поезију која се пише и чита, а не пева (Христић 2016: 159), а као чијег представника Христић види Јована Стерију Поповића. Довољно је само евоцирати наслов Стеријине песме Спомен путовања по дольим пределима Дунава, па да се веза на мотивском, идејном и филозофском плану сама укаже, те да 
се променљивост узме као константа песничког и филозофског система двојице песника.

Сензибилитет модерног субјекта који Јован Христић у својој поезији представља одређен је и схватањем судбине, која се показује исто тако неодређена и у зависности од човековог избора. Ипак, да би човек начинио избор, потребно је да се погледом у себе суочи са фантомским облицима свог постојања који вребају између четири зида.

У том смислу, можемо и закључити да поезија Јована Христића настаје „У очима, као огледалима која једно друго исцрпљују.” (56)

\section{ЛИТЕРАТУРА}

Христић 1996: Ј. Христић, Сабране песме (прир. И. В. Лалић), Нови Сад: Матица српска.

Христић 2002: Ј. Хриситћ, Сабране песме (прир. С. Радојчић), Београд: Рад.

Христић 2016: Ј. Христић, Изабрана дела (прир. Б. Стојановић Пантовић), Антологијска едиција Десет векова српске књижевности, књ. 89, Нови Сад: Матица српска.

Аврамовић 2009: М. Аврамовић, Јован Христић - Критичар поезије, у: А. Јовановић (ур.), Модерни класициста Јован Христић, Београд: Институт за књижевност и уметност / Учитељски Факултет, 55-124.

Елиот 1957: Т. С. Елиот, Поезија и филозофија (превео Роберт Фишер) у: Поља: месечник за уметност и културу, год. 3, бр. 4, стр. 2-3.

Елиот 1963: Т. С. Елиот, Изабрани текстови, Београд: Просвета.

Лалић 1996: И. В. Лалић, Прелегомена за једно читање поезије Јована Христића, у: Ј. Хриситћ, Сабране песме, Нови Сад: Матица Српска, 7-19.

Новаковић 2013: Ј. Новаковић, Медитеранска надахнућа у српској поезији XX века: компаратистичка перспектива, у: С. Шеатовић Димитријевић et al. (ур), Acqua alta : међународни зборник радова = miscellanea internazionale. Медитерански пејзажи у модерној српској и италијанској кьижевности = Paesaggi mediterranei nelle litterature italiana e serba del novecento, Београд: Институт за књижевност и уметност, 435-453.

Петров 2009, А. Петров, Христићев Улис, у: А. Јовановић (ур.), Модерни класициста Јован Христић, Београд: Институт за књижевност и уметност / Учитељски Факултет, 55-124. 
Радојчић 2009: С. Радојчић, Јован Христић, песник, у: Ј. Христић, Сабране песме (прир. С. Радојчић), Београд: Рад.

Радојчић 2016: С. Радијчић, Филозофски аспекти Христићеве есејистике, у: Ј. Христић, Изабрана дела (прир. Б. Стојановић Пантовић), Антологијска едиција Десет векова српске књижевности, књ. 89, Нови Сад: Матица српска, 214-219.

Христић 1957: Ј. Христић, Поезија и критика поезије, Нови Сад: Матица српска.

Христић 1964: Ј. Христић, Поезија и филозофија, Нови Сад: Матица српска.

Христић 1969: Ј. Христић, Предговор, у: И. В. Лалић 1969: Изабране u нове песме, Београд: Српска књижевна задруга.

Tijana M. Koprivica

\section{„FROM YOU TO THE EARTH, FROM YOU TO THE STARS, IT IS THE SAME” - A GLANCE AT JOVAN HRISTIĆ'S POETRY}

\section{Summary}

The purpose of this paper will be to offer a look at poetry of Jovan Hristic from the perspective of New Criticism, which Hristić himself adopted and appreciated as an intermediary between the Anglo-Saxon Critical Circle and Serbian literature, both in writing poetry and in critical thinking about it. In this case, the focus will be on those issues that Hristic has dealt with in interpreting the poetry of other poets, that is, the relationship between poetry and philosophy that occupied him, and will thus explore this issue through four strong points: tradition, travel, space and relationship between certainty and fortuity.

Key words: Jovan Hristić (1933-2002), New Criticism, poetry, philsophy, Serbian literature, tradition, travel, space, certainty, fortuity. 